\title{
Validity of the Brazilian Portuguese version of the bipolar spectrum diagnostic scale
}

\author{
Validade da versão brasileira em português da \\ escala diagnóstica do espectro bipolar
}

Milena S. Casteloㅇ, Eduardo R. Carvalho², Emília S. Gerhard², Danielle Silveira Macêdo³, Eduardo D. Ferreira ${ }^{4}$, André F. Carvalho

\begin{abstract}
Objective: Bipolar spectrum disorders (BSDs) are prevalent and frequently unrecognized and undertreated. This report describes the development and validation of the Brazilian version of the bipolar spectrum diagnostic scale (B-BSDS), a screening instrument for bipolar disorders, in an adult psychiatric population. Method: 114 consecutive patients attending an outpatient psychiatric clinic completed the B-BSDS. A research psychiatrist, blind to the B-BSDS scores, interviewed patients by means of a modified version of the mood module of the Structured Clinical Interview for DSM-IV ("gold standard"). Subthreshold bipolar disorders were defined as recurrent hypomania without a major depressive episode or with fewer symptoms than those required for threshold hypomania. Results: The internal consistency of the B-BSDS evaluated with Cronbach's alpha coefficient was 0.89 ( $95 \% \mathrm{Cl} ; 0.86-0.91)$. On the basis of the modified SCID, 70 patients (61.4\%) of the sample received a diagnosis of BSDs. A B-BSDS screening score of 16 or more items yielded: sensitivity of 0.79 ( $95 \% \mathrm{Cl}$; $0.72-0.85)$, specificity of 0.77 ( $95 \% \mathrm{Cl}$; $0.70-0.83)$, a positive predictive value of $0.85(95 \% \mathrm{Cl}$; $0.78-0.91)$ and a negative predictive value of 0.70 ( $95 \% \mathrm{Cl} ; 0.63-0.75)$. Conclusion: The present data demonstrate that the B-BSDS is a valid instrument for the screening of BSDs.
\end{abstract}

\section{RESUMO}

Objetivo: Transtornos do espectro bipolar (TEB) são prevalentes e comumente subdiagnosticados e subtratados. O presente trabalho descreve o desenvolvimento e a validação da versão brasileira da escala diagnóstica do espectro bipolar (B-EDEB), um instrumento de rastreio para transtornos bipolares, em uma população psiquiátrica adulta. Método: 114 pacientes consecutivos de um ambulatório psiquiátrico completaram a versão brasileira da B-EDEB. Um psiquiatra pesquisador, cego para os escores do B-EDEB, entrevistou os participantes por meio de uma versão modificada do módulo de transtornos do humor da entrevista clínica estruturada para o DSM-IV ("padrão-ouro"). Resultados: A consistência interna da B-EDEB, avaliada mediante o coeficiente alfa de Cronbach, foi de 0,89 (IC 95\%; 0,86-0,91). De acordo com o padrão-ouro, 70 (61,4\%) participantes tiveram diagnóstico de TEB. Um escore da B-EDEB de 16 ou mais itens apresentou sensibilidade de 0,79 (IC 95\%; 0,72-0,85), especificidade de 0,77 (IC 95\%; 0,70-0,83), valor preditivo positivo de 0,85 (IC 95\%; 0,78-0,91) e valor preditivo negativo de 0,70 (IC 95\%; 0,63-0,75). Conclusão: Os resultados do presente estudo demonstram que a B-EDEB é um instrumento válido para o rastreio de TEB.

1 Universidade de Fortaleza (Unifor), Faculty of Medicine, Fortaleza, CE.

2 Universidade Federal do Ceará (UFC), Faculty of Medicine, Department of Clinical Medicine, Fortaleza, CE.

Recebido em

$16 / 7 / 2010$

Aprovado em

$16 / 9 / 2010$

3 UFC, Faculty of Medicine, Department of Physiology and Pharmacology.

4 Hospital Psiquiátrico São Pedro, Porto Alegre, RS.

Endereço para correspondência: André F. Carvalho

Departamento de Medicina Clínica, Faculdade de Medicina, UFC

Rua Professor Costa Mendes, 1608, $4^{\circ}$ andar - 60430-040 - Fortaleza, Ceará, Brasil.

Telefax: (+55 85) 3261-7227

E-mail:andrefc7@terra.com.br 


\section{INTRODUCTION}

The U.S. National Comorbidity Survey Replication (NCS-R - $\mathrm{n}$ $=9,282$ ) reported lifetime (and 12-month) prevalence estimates of $1.0 \%(0.6 \%)$ for type I bipolar disorder (BD), 1.1\% (0.8\%) for type II BD and 2.4\% (1.4\%) for subthreshold BD'. The disorder is of significant burden and economic impact in the general population. It is ranked as the eighth leading cause of medical disability worldwide ${ }^{2}$. Bipolar disorders are associated with medical and psychiatric morbidity ${ }^{3}$, as well as functional impairment ${ }^{4}$ and elevated suicide rates ${ }^{5}$.

Despite its public health impact, bipolar disorders are frequently unrecognized in various settings, often misdiagnosed as major depression, and inadequately treated ${ }^{6,7}$. The resultant delayed diagnosis might have long-term adverse effects on several aspects of bipolar disorder (e.g., cognition and functioning $)^{8}$.

Recently, Ronald Pies developed a comprehensive screening questionnaire that aimed to screen the whole spectrum of bipolar disorders, including the so-called soft bipolarity cases. Hence, this instrument was named the bipolar spectrum diagnostic scale. The sensitivity and specificity of the instrument was assessed on 68 outpatients with bipolar spectrum disorder. The sensitivity was 0.76 and the specificity was $0.85^{9}$.

There are more than 200 million Portuguese speakers all over the world, in locations including Portugal, Brazil, Cape Verde, Guinea-Bissau, Mozambique and Sao Tome and Principal Islands. Portuguese ranks eighth among the most spoken languages in the world. The present research aimed to develop and validate a Brazilian Portuguese version of the BSDS (B-BSDS) in a consecutive sample of psychiatric outpatients. This work is part of a major effort to improve the detection of bipolar spectrum disorders.

\section{METHOD}

This study was conducted at the outpatient clinics of the Hospital de Saúde Mental de Messejana. This mental health care facility receives, mainly from primary care health services, a large number of patients for diagnostic evaluation and treatment of mood disorders.

The study protocol was approved by the Ethics Committee of the Hospital Universitário Walter Cantídio (Faculty of Medicine/Federal University of Ceará). Signed informed consent was obtained for each subject prior to inclusion in the present study.

\section{Instruments and procedures}

The BSDS was first translated into Portuguese by two bilingual authors of the present study (psychiatrists). To ensure that the connotative meaning of items was not altered in the translation, it was back translated into English by a third mental health professional of English mother tongue. The three approved a final version. For the evaluation of semantic equivalence, both the reference and general meanings of words and items were considered. The reference meaning underlies the ideas and objects to which one or more words refer to. The general meaning take into account the impact these words assume in the cultural context of the target population. In order to evaluate if the initial translation was properly performed, a pilot analysis was done with five patients.

A convenience sample of 114 consecutive patients took part in this investigation. This sample size was estimated to detect a sensitivity of 0.80 with a minimal acceptable lower confidence limit of 0.70 for the BSDS ${ }^{10}$.

The BSDS is a self-report narrative-based scale developed by Ronald Pies, which was revised and validated by Ghaemi et al. ${ }^{9}$. It consists of a one-page story in the first part - containing 19 positively valenced sentences, as third person, included some typical mood swing experiences - and one simple multiple-choice question in the second part to rate how well the story describes oneself.

A senior medical student initially met each patient and completed a questionnaire with socio-demographic data and the B-BSDS. The participants were then referred to a study psychiatrist in charge of conducting the diagnostic interview. The psychiatrist was trained to administer the mood module of the Structured Clinical Interview for the DSM-IV $(\mathrm{SCID})^{11}$, as modified according to procedures of the U.S. National Comorbidity Survey Replication'. Briefly, subthreshold bipolarity included any of the following: (1) recurrent subthreshold hypomania ( $\geq 2$ criterion B symptoms and all other criteria for hypomania) in the presence of intercurrent major depressive episode (MDE), (2) recurrent ( $\geq 2$ episodes) hypomania in the absence of recurrent MDE with or without subthreshold MDE, and (3) recurrent subthreshold hypomania in the absence of intercurrent MDE. The number of required symptoms for a determination of subthreshold hypomania was confined to 2 criterion B symptoms (from the DSM-IV requirement of 3 , or 4 if the mood is only irritable) to retain the core features of soft hypomania.

\section{Statistical analyses}

Statistical analyses were carried out with the Statistical Package for the Social Sciences (SPSS) version 14.0 for Windows and the STATA version 10.0 for Windows. The area under the receiver operating characteristic (ROC) curve (with 95\% Cl) was determined. Operating characteristics of the B-BSDS were calculated from $2 \times 2$ contingency tables and reported as estimates of sensitivity, specificity, positive predictive value and negative predictive value (criterion validity). For Internal consistency reliability, the Cronbach's alpha coefficient value (with 95\% Cl) for the B-BSDS was determined. 


\section{RESULTS}

The initial back-translated version of the BSDS was considered equivalent to the original version of the instrument (Appendix). The B-BSDS was well understood by patients during pilot interviews.

\section{Description of the sample}

The study included 114 patients (34 males, 80 females). Mean age was 42.7 years $(S D=12.9)$. Among them, $70(61.4 \%)$ received a diagnosis of bipolar spectrum disorder (bipolar $\mathrm{l}: \mathrm{n}=$ 55; bipolar II: $n=6$; and bipolar disorder not otherwise specified: $n=9$ ). Among bipolar patients, a delay of $6.9 \pm 3.5$ years from symptom onset and treatment initiation was observed.

\section{Internal consistency reliability}

Corrected item-total score correlations varied from 0.30 (item 19) to 0.78 (item 2). All the correlations were significant (at $\mathrm{p}<0.01$; Spearman's test). A Cronbach's alpha coefficient for the B-BSDS of 0.89 (95\% Cl; 0.86-0.92) was obtained.

\section{Sensitivity, specificity and predictive values}

The area under the ROC curve was 0.81 (95\% Cl; 0.72-0.89) (Figure 1). A cutoff of 16 was selected for optimum balance between sensitivity and specificity. The operating parameters at this cutoff score were, as follows: sensitivity of 0.79 (95\% Cl; 0.72-0.85); specificity of 0.77 (95\% Cl; 0.70-0.83); positive predictive value of 0.85 (95\% Cl; 0.78- 0.91$)$; and a negative predictive value of 0.70 (95\% Cl; 0.63-0.75) (Table 1).

Appendix. Escala Diagnóstica do Espectro Bipolar (EDEB)

Instruções - Por favor, leia o texto inteiro antes de preencher os espaços em branco.

Algumas pessoas notam que seu humor e nível de energia mudam radicalmente de uma fase para outra. ______ Essas pessoas notam que, às vezes, seu humor e/ou nível de energia está muito baixo e às vezes está muito alto. __ Durante essas fases "para baixo", essas pessoas sentem sempre falta de energia, têm necessidade de ficar na cama ou de dormir mais e têm pequena ou nenhuma vontade de fazer as coisas que precisam ser feitas. ______Elas geralmente aumentam de peso durante esses períodos. ______ Durante as fases "para baixo", essas pessoas se sentem desanimadas, tristes ou deprimidas o tempo todo. Algumas vezes, durante essas fases "para baixo", se sentem sem esperança e pensam em morrer ou se matar. ______ 0 desempenho no trabalho ou nas atividades sociais é prejudicado. ______ Essas fases "para baixo" duram poucas semanas, mas algumas vezes duram somente poucos dias. _-_-_ As pessoas com esse comportamento podem experimentar um período de humor "normal" entre os períodos de variação de humor; durante essas fases o humor e a energia estão normais e a capacidade de funcionar não sofre nenhuma alteração.______Podem, depois, mudar de repente ou terem uma reviravolta no jeito de sentir as coisas. A energia aumenta acima do normal para elas e elas geralmente fazem muitas coisas que normalmente não fariam. Geralmente, durante essas fases "para cima", essas pessoas sentem como se tivessem muita energia ou se sentem o máximo.______ Essas pessoas durante as fases "para cima" se sentem irritadas, no limite ou agressivas.______ Algumas pessoas durante essas fases "para cima" se envolvem em muitas atividades ao mesmo tempo. ______ Durante esses períodos "para cima", algumas pessoas podem gastar dinheiro de um jeito que cria problemas para elas. Durante essas fases, elas podem ficar mais falantes, mais dadas ou terem mais vontade de ter relações sexuais._ Algumas vezes, durante essas fases "para cima", seus comportamentos parecem estranhos ou irritam os outros. _______ Algumas vezes, essas pessoas se envolvem em problemas com colegas do trabalho ou com a polícia durante esses períodos "para cima." ______ Algumas vezes, elas aumentam o uso do álcool ou de outras drogas ilícitas durante essas fases "para cima".

Agora que você leu o texto inteiro, por favor, marque uma das quatro opções:

( ) Esta história tem tudo ou quase tudo a ver comigo.

( ) Esta história tem mais ou menos a ver comigo.

( ) Esta história tem pouco a ver comigo.

( ) Esta história não tem nada a ver comigo.

Agora, por favor, volte e coloque um " $\mathrm{X}$ " depois de cada frase que definitivamente tenha a ver com você.

Pontuação - Cada sentença assinalada vale um ponto. Adicione 6 pontos para "tem tudo ou quase tudo a ver comigo", 4 pontos para "tem mais ou menos a ver comigo" e 2 pontos para "tem pouco a ver comigo".

Table 1. Sensitivity, specificity and predictive values of the B-BSDS for various cutoff scores

\begin{tabular}{llll}
\hline Cutoff score & Sensitivity $(95 \% \mathrm{Cl})$ & Specificity (95\% Cl) & \multicolumn{1}{c}{ Positive predictive value (95\% Cl) } \\
\hline 14 & $85.7 \%(79.2-92.2)$ & $61.4 \%(54.9-67.8)$ & $77.9 \%(71.5-84.4)$ \\
15 & $82.8 \%(76.4-89.3)$ & $68.2 \%(61.7-74.6)$ & $85.3 \%(78.8-91.8)$ \\
16 & $78.5 \%(72.1-85)$ & $77.3 \%(70.8-83.7)$ & $84.6 \%(78.1-91.1)$ \\
17 & $70 \%(63.5-76.5)$ & $77.3 \%(70.8-83.7)$ & $83.1 \%(76.6-89.5)$ \\
18 & $58.5 \%(52.1-65)$ & $79.5 \%(73.1-86)$ & $82.0 \%(75.5-88.5)$ \\
\hline
\end{tabular}




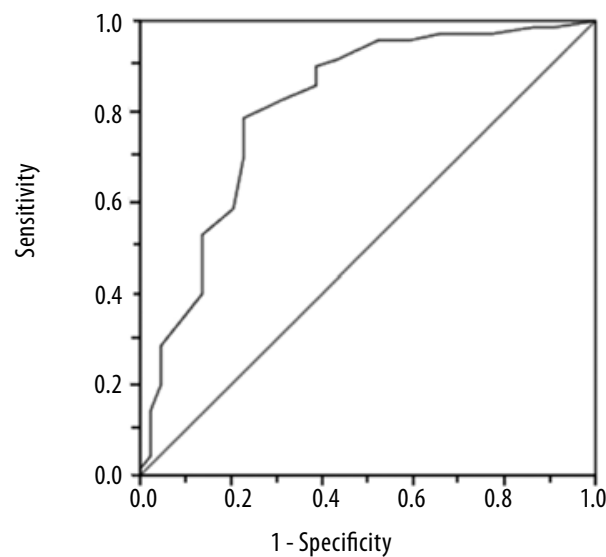

Figure 1. Receiver operating characteristics (ROC) curve for the B-BSDS in the whole sample.

\section{DISCUSSION}

As far as we know, this was the first study to assess the validity of the bipolar spectrum diagnostic scale in Brazilian samples. The psychometric properties of the B-BSDS were similar to those of the original English version of the instrument. The cutoff of 16 was optimum for the B-BSDS, whereas a cutoff of 13 was chosen for the original version. In the study by Ghaemi et al. ${ }^{9}$ the bipolar not otherwise specified (NOS) group was incremented according to the somewhat over-inclusive guidelines proposed by Akiskal and Pinto ${ }^{12}$. In the present study, we applied for the diagnosis of bipolar NOS the extended criteria used in the NCS-R study. The bipolar NOS group of the NCS-R study was significantly impaired and the data were drawn from a representative US population sample (therefore, increasing external validity of the criteria) ${ }^{1}$.

We are aware of a single study that tried to validate the BSDS in a different cultural milieu. The Persian version of the BSDS was not as sensitive and specific as the original one ${ }^{13}$. However, the discrepant data might have been due to differences in "gold-standard" criteria used (i.e., the authors used the strict DSM-IV definition) ${ }^{13}$. Thus, some bipolar NOS patients might have been classified as lacking a bipolar spectrum disorder.

There are limitations to the present study. Insight into illness was not assessed. However, a recent study did not demonstrate a negative impact of insight level on psychometric properties of another screening instrument (i.e., the mood disorder questionnaire) $)^{14}$. A significant relationship between BSDS and the Scale to Assess Unawareness of Mental Disorder (SUMD) scores was not observed ${ }^{9}$. Furthermore, current mood symptoms of the participants were not evaluated through standard rating scales (e.g., Montgomery- Åsberg depression rating scale, Young mania rating scale). The psychometric properties of the B-BSDS might vary as a function of symptom severity.
Bipolar disorder type I is clearly over-represented in this study. This might be explained by the fact that our sample derived from a tertiary psychiatric clinic, in which more severe cases are treated. Separate analyses of the B-BSDS screening properties for the detection of bipolar type II/NOS could not be performed due to inadequate statistical power.

The true prevalence of bipolar spectrum disorders in primary care is uncertain. Previous studies have estimated the prevalence of bipolar disorders between $0.7 \%$ and $1.2 \%{ }^{15-17}$. Recently, Das et al..$^{18}$ found a prevalence of $9.8 \%$ for this group of disorders in a primary care practice. The same authors demonstrated that only $6.5 \%(n=7)$ reported taking a mood stabilizing agent in the month before interview. The differences in prevalence rates across studies might reflect differences in the accuracy of screening instruments for the detection of milder cases ${ }^{19}$. Primary care practices might prove to be the optimum environments for screening bipolar spectrum disorders.

The promising results of the present work encourage the design of future studies to assess the psychometric properties of the B-BSDS in primary care settings. These data represent part of a major effort to improve recognition and ultimate treatment of bipolar spectrum disorders.

\section{CONCLUSION}

The Brazilian Portuguese version of the BSDS is a brief and feasible method for improving the recognition of bipolar spectrum disorders among psychiatric clinical samples. The B-BSDS psychometric data are in the range of other valid instruments used to screen psychiatric disorders. Additional studies are needed to determine the performance of this instrument in other populations (e.g., community and primary care). It should be emphasized that screening instruments are not a substitute for a comprehensive psychiatric evaluation. However, the B-BSDS might aid in the correct detection and/or exclusion of the whole spectrum of bipolar disorders.

\section{REFERENCES}

1. Merikangas KR, Akiskal HS, Angst J, et al. Lifetime and 12-month prevalence of bipolar spectrum disorder in the National Comorbidity Survey Replication. Arch Gen Psychiatry. 2007:64(5):543-52.

2. Murray (J, Lopez AD. Evidence-based health policy - lessons from the Global Burden of Disease Study. Science. 1996;274(5288):740-3

3. Krishnan KR. Psychiatric and medical comorbidities of bipolar disorder. Psychosom Med. 2005;67(1):1-8.

4. Calabrese JR, Hirschfeld RM, Reed M, Davies MA, Frye MA, Keck PE, et al. Impact of bipolar disorder on a U.S. community sample. J Clin Psychiatry. 2003;64(4):425-32.

5. Harris EC, Barraclough B. Suicide as an outcome for mental disorders: a meta-analysis. Br J Psychiatry. 1997;170:205-28. 
6. Hirschfeld RM, Lewis L, Vornik LA. Perceptions and impact of bipolar disorder: how far have we really come? Results of the national depressive and manic-depressive association 2000 survey of individuals with bipolar disorder. J Clin Psychiatry. 2003;64(2):161-74.

7. Lish JD, Dime-Meenan S, Whybrow PC, Price RA, Hirschfeld RM. The National Depressive and Manic-depressive Association (DMDA) survey of bipolar members. J Affect Disord. 1994;31(4):281-94.

8. Berk M, Malhi GS, Hallam K, Gama CS, Dodd S, Andreazza AC, et al. Early intervention in bipolar disorders: clinical, biochemical and neuroimaging imperatives. J Affect Disord. 2009;114(1-3):1-13.

9. Ghaemi SN, Mille CJ, Berv DA, Klugman J, Rosenquist KJ, Pies RW. Sensitivity and specificity of a new bipolar spectrum diagnostic scale. J Affect Disord. 2005;84:273-7.

10. Flahault A, Cadilhac M, Thomas G. Sample size calculation should be performed for design accuracy in diagnostic test studies. J Clin Epidemiol. 2005;58(8):859-62.

11. Del Ben CM, Vilela JA, Crippa JA, Hallak JE, Labate CM, Zuardi AW. Confiabilidade da "Entrevista Clínica Estruturada para o DSM-IV - Versão Clínica" traduzida para o português. [Reliability of the structured interview for the DSM-IV- clinical scale translated to Portuguese]. Rev Bras Psiq. 2001;23(3):156-9.

12. Akiskal HS, Pinto 0 . The evolving bipolar spectrum. Prototypes I, II, III, and IV. Psychiatr Clin North Am. 1999;22(3):517-34, vii.
13. Shabani A, Koohi-Habibi L, Nojomi M, Chimeh N, Ghaemi SN, Soleimani N. The Persian Bipolar Spectrum Diagnostic Scale and mood disorder questionnaire in screening the patients with bipolar disorder. Arch Iran Med. 2009;12(1):41-7.

14. Miller (J, Klugman J, Berv DA, Rosenquist KJ, Ghaemi SN. Sensitivity and specificity of the Mood Disorder Questionnaire for detecting bipolar disorder. J Affect Disord. 2004;81(2):167-71

15. Blacker $(V$, Clare AW. The prevalence and treatment of depression in general practice. Psychopharmacology (Berl). 1988;95(Suppl):S14-7.

16. Olfson M, Fireman B, Weissman MM, Leon AC, Sheehan DV, Kathol RG, et al. Mental disorders and disability among patients in a primary care group practice. Am J Psychiatry. 1997;154:1734-40

17. Schulberg HC, Saul M, McClelland M, Ganguli M, Christy W, Frank R. Assessing depression in primary medical and psychiatric practices. Arch Gen Psychiatry. 1985;42:1164-70

18. Das AK, Olfson M, Gameroff MJ, Pilowsky DJ, Blanco C, Feder A, et al. Screening for bipolar disorder in a primary care practice. JAMA. 2005;293(8):956-63.

19. Hantouche $E G$, Angst J, Akiskal, HS. Factor structure of hypomania: interrelationships with cyclothymia and the soft bipolar spectrum. J Affect Disord. 2003;73:39-47. 